\title{
Inquiry Learning Model to improve Social Studies Learning Outcomes in Class V SD Negeri 59 North Bengkulu
}

\section{Model Pembelajaran Inquiry untuk meningkatkan Hasil Belajar IPS Pada Siswa Kelas V SD Negeri 59 Bengkulu Utara}

\author{
Lindawati \\ SD Negeri 59 Bengkulu Utara, Bengkulu \\ E-mail: lidiawati.bkl@gmail.com
}

Received 25 Januari 2020, Revised 25 Maret 2020, Accepted 30 April 2020

\begin{abstract}
This Research aim to to increase process the study IPS of to be can please and make the student become active. Applying model the study Inquiry can improve the result learn the IPS of student in the class V SD Negeri 59 Bengkulu Utara of teaching year 2593 / 2594. This Research type is Classroom Action Research (PTK) by using model of Kemmis and Mc. Taggart, by subjek is research that is students in the class V SDN 59 Bengkulu Utara amounting to 23 student and object in this research is the make-up of result learn the student at subject IPS. Action conducted by during this research is study execution by using model Inquiry. Technique of data collecting used by is problem tes of [is breakdown of and Technique observation analyse the data conducted by dekriptif qualitative and quantitative descriptive Result of research indicate that through applying model the Inquiry in study IPS can improve the result learn the student. Make-Up of result learn this student is seen from the increasing of student ability in searching answer from problems of through various step in model Inquiry that is orient, formulating problem, formulating hypothesis, collecting data or information, conducting hypothesis test, and formulate the conclusion. With refer to the step in model inkuri of besides improving result learn also improve the student livelines in course of study of where student instructed to go it alone to to look for answers to question which have dirumusakan. Make-Up of result learn the student seen from the increasing of complete percentage result of tes student of where at cycle I from $74 \%$ and mount again at cycle II become $91 \%$.
\end{abstract}

Keywords: Model the Inquiry, Result of learning IPS.

\begin{abstract}
Abstrak
Penelitian ini bertujuan untuk meningkatkan proses pembelajaran IPS agar dapat menyenangkan dan membuat siswa menjadi aktif. Menerapkan model penelitian Inquiry dapat meningkatkan hasil belajar IPS siswa di kelas V SD Negeri 59 Bengkulu Utara tahun ajaran 2593/2594. Jenis penelitian ini adalah Penelitian Tindakan Kelas (PTK) dengan menggunakan model Kemmis dan Mc. Taggart, menurut subjek adalah penelitian yaitu siswa di kelas V SDN 59 Bengkulu Utara berjumlah 23 siswa dan objek dalam penelitian ini adalah peningkatan hasil belajar siswa pada mata pelajaran IPS. Tindakan yang dilakukan selama penelitian ini adalah pelaksanaan pembelajaran dengan menggunakan model Inquiry. Teknik pengumpulan data yang digunakan adalah masalah tes dan teknik observasi menganalisis data yang dilakukan secara deskriptif kualitatif dan kuantitatif deskriptif. Hasil penelitian menunjukkan bahwa melalui penerapan model Inquiry in study IPS dapat meningkatkan hasil belajar siswa. Peningkatan hasil belajar siswa ini terlihat dari meningkatnya kemampuan siswa dalam mencari jawaban dari masalah melalui berbagai langkah dalam model inkuiri yaitu berorientasi, merumuskan masalah, merumuskan hipotesis, mengumpulkan data atau informasi, melakukan uji hipotesis, dan merumuskan kesimpulan. Dengan mengacu pada langkah dalam model inkuri selain meningkatkan hasil belajar juga meningkatkan kehidupan siswa dalam proses studi di mana siswa diinstruksikan untuk pergi sendiri untuk mencari jawaban atas
\end{abstract}


pertanyaan yang telah dirumusakan. Peningkatan hasil belajar siswa terlihat dari meningkatnya persentase hasil tes siswa yang lengkap dimana pada siklus I dari 74\% dan meningkat lagi pada siklus II menjadi $91 \%$.

Kata kunci: Model Inquiry, Hasil Pembelajaran IPS.

\section{A. Pendahuluan}

Pendidikan di sekolah dasar harus dilaksanakan secara terencana agar dapat mewujudkan proses pembelajaran yang menyenangkan dan dapat mengembangkan potensi siswa secara optimal, sehingga ketika siswa dalam mengembangkan potensi yang dimilikinya dapat dikembangkan secara baik dan aktif. Keaktifan siswa dalam pembelajaran sangat penting karena proses pembelajaran dapat berjalan dengan baik apabila ada interaksi antara siswa dan guru atau sumber belajar lainnya. Keaktifan siswa tersebut menandakan bahwa pembelajaran tidak hanya berjalan satu arah. Siswa akan merasa senang apabila terlibat aktif secara langsung dalam kegiatan pembelajaran dan siswa juga merasa tertarik, antusias dalam mengikuti pembelajaran sehingga dengan demikian maka tujuan pembelajaran dapat tercapai dengan baik yang bertujuan untuk meningkatkan hasil belajar siswanya.

Salah satu muatan pelajaran yang ada di tingkat pendidikan dasar adalah IImu Pengetahuan Sosial. Menurut Fakih Samlawih dan Bunyamin Maftuh ( 1998 :1) mengatakan bahwa ilmu pengetahuan sosial merupakan mata pelajaran yang memadukan konsep dasar dari berbagai ilmu sosial yang disusun melalui pendekatan pendidikan dan psikologis serta kelayakan dan atau kebermaknaannya bagi siswa dan kehidupannya. Pembelajaran IPS ini akan sangat bermakna dan menyenangkan apabila siswa mengalami secara langsung bukan hanya sekedar mengetahui, khususnya untuk Siswa SD yang masih dalam tahap perkembangan operasional konkret, dimana siswa memiliki sifat keingintahuan yang tinggi akan sesuatu hal dan belajar akan hal-hal yang bersifat konkret atau nyata.

Tingkat perkembangannya siswa SD belum mampu memahami keluasan dalam masalah-masalah sosial secara utuh, akan tetapi siswa dapat diperkenalkan kepada masalah-masalah tersebut. Pembelajaran IPS pada intinya memperkenalkan kepada siswa bahwa manusia dalam hidup bersama dituntut rasa tanggung jawab sosial. Melalui pembelajaran IPS siswa dapat memperoleh pengetahuan, keterampilan, sikap serta kepekaan untuk menghadapi hidup beserta segenap tantangantantangannya sehingga kelak diharapkan bertindak secara rasional dalam memecahkan masalah-masalah sosial yang dihadapinya.

Sehubungan hal itu, guru pada saat ini dituntut memiliki kompetensi dan kerja yang professional. Tujuan guru dalam pembelajaran sendiri adalah melakukan pembelajaran dengan baik, tuntas dan berhasil. Keberhasilan pembelajaran di dalam kelas teridentifikasi dari tercapainya nilai diatas KKM. Akan tetapi harapan kadang tidak sesuai dengan kenyataan yang ada.

Berdasarkan hasil pemetaan nilai pelajaran IPS Kelas V SD Negeri 59 Bengkulu Utara pada tahun pelajaran 2593/2594, didapatkan bahwa nilai hasil belajar pada pokok bahasan materi "Faktor pemicu terjadinya beberapa peristiwa pertempuran" dari 23 siswa Kelas $\mathrm{V}$ yang tuntas belajar hanya mencapai $61 \%$ atau 14 siswa. Selebihya $39 \%$ atau 9 siswa belum mencapai nilai tuntas atau dibawah KKM IPS yaitu 70 . 
Berangkat dari rendahnya nilai hasil belajar yang dicapai siswa hanya mencapai $61 \%$ tuntas dan criteria yang telah ditetapkan adalah $80 \%$ dari jumlah siswa tuntas maka peneliti berinisiatif melakukan penelitian dampak penerapan dari metode pembelajaran inquiry dengan tujuan utama adalah meningkatkan hasil belajar siswa Kelas $\mathrm{V}$ pada mata pelajaran IPS pokok bahasan "Faktor pemicu terjadinya beberapa peristiwa pertempuran".

\section{B. Metode Penelitian Subyek Penelitian}

Subjek dalam penelitian ini adalah siswa kelas V SD 59 Bengkulu Utara yang berjumlah 23 siswa dengan jumlah perempuan 10 orang dan laki-laki 13 orang. Siswa kelas V dipilih sebagai subjek penelitian karena masih rendahnya hasil belajar IPS siswa yakni dari jumlah siswa 23 masih 9 siswa yang belum mencapai KKM sementara yang sudah mencapai KKM adalah 14 siswa. Setting penelitian dilaksanakan di dalam Kelas. Objek penelitian pada penelitian ini adalah peningkatan hasil belajar siswa pada mata pelajaran IPS siswa kelas V SD Negeri 59 Bengkulu Utara pada materi "Faktor pemicu terjadinya beberapa peristiwa pertempuran".

Selanjutnya agar dokumen pengamatann aktivitas siswa dan guru selama pembelajaran teramati maka peneliti meminta bantuan 1 orang guru sejawat sebagai observer. Penelitian tindakan ini dilakukan pada semester II tahun pelajaran 2593/2594 bulan Maret 2594 dan peneliti menyusun jadwal pelaksanaan tindakan sebagai berikut 1) Siklus I : Rabu, 12 Maret 2594 dan 2) Siklus II : Rabu, 19 Maret 2594.

\section{Prosedur Penelitian}

Pada penelitian ini model penelitian yang digunakan yaitu mengacu pada model penelitian yang dikembangkan oleh Kemmis dan McTaggart (Suharsimi Arikunto, 2006:93) yaitu dalam bentuk spiral mulai dari tahap rencana, tindakan, observasi dan refleksi. Berikut ini desain gambar yang dikembangkan oleh Kemmis dan Mc.Taggart. Adapun penjelasan dari masing-masing tahapan dalam penelitian ini adalah sebagai berikut:

Perencanaan (Plann)Tahapan ini dimulai dari penemuan masalah kemudian merancang tindakan yang akan dilakukan. Langkah-langkah yang akan dijelaskan secara rinci berikut ini :

a. Menemukan Masalah di Lapangan, yaitu:

1) Peneliti menganalisis nilai hasil belajar siswa pad mata pelajaran IPS materi "Faktor pemicu terjadinya beberapa peristiwa pertempuran". Dari hasil analisis ditemukan masalah siswa masih banyak yang belum tuntas belajar dan target keberhasilan belajar $80 \%$ dari jumlah siswa belum terpenuhi.

2) Peneliti menganalisa masalah pembelajaran berdiskusi dengan rekan guru lainnya terkait proses pembelajaran yang berhubungan dengan hasil belajar IPS, dan menyimpulkan bahwa salah satu faktor penyebab rendahnya hasil belajar IPS adalah karena model pembelajaran yang digunakan yang dikuasai guru masih terbatas.

3) Berdasarkan hasil diskusi peneliti dengan rekan sejawat tersebut maka eneliti menarik solusi atau menindak lanjuti masalah tersebut dengan menggunakan model pembelajaran Inquiry dalam rangka untuk meningkatkan hasil belajar siswa kelas $\mathrm{V}$ pada mata pelajaran IPS

b. Merancang Tindakan Yang Akan Dilakukan

Setelah peneliti mengatahui permaalahan yang terjadi, kemudian peneliti menyusun rencana tindakan sebagai solusi permasalahan yang ada dalam rangka memperbaiki dan meningatkan hasil belajar siswa kelas $\mathrm{V}$ ada mata pelajaran IPS.

Perencanaan tindakan yang dimaksud adalah persiapan perencanaan tindakan pembelajaran dengan menggunakan model pembelajaran Inquiry dengan langkahlangkah berikut:

1) Menyusun rencana tindakan pembelajaran siklus I yang dituangkan 
dalam RPP, namun perencanaan yang dibuat masih bersifat fleksibel terhadap perubahan dalam pelaksanaannya.

2) Menentukan bahan, materi dan media pembelajaran yang akan digunakan dalam pembelajaran.

3) Menyusun instrumen penelitian yaitu lembar observasi dan pedoman wawancara.

Tindakan (Action) Tahap pelaksanaan tindakan adalah tahapan mengimplementasikan rencana tindakan yang telah disusun, selanjutnya guru melakukan tindakan sesuai dengan RPP yang telah dibuat. Tindakan yang dilakukan dalam penelitian ini adalah pembelajaran IPS melalui model Inquiry.

Pengamatan (Observation) Tahap ini merupakan kegiatan observer untuk mengamati proses aktivitas guru dan siswa terhadap dampak dari tindakan pembelajaran menggunakan lembar observasi yang sudah dibuat. Pada tahap ini peneliti melakukan pengamatan terhadap hasil belajar siswa di kelas dengan menggunakan lembar penilaian.

Refleksi (Reflextion) Tahap refleksi merupakan tahapan evaluasi terhadap hasil tindakan yang telah dilakukan. Pada tahap ini, peneliti bersama observer menganalisa dan mempertimbangkan data hasil observasi yang diperoleh. Apabila data yang diperoleh dari siklus I masih belum mencapai kriteria keberhasilan dan masih memerlukan perbaikan, maka dilakukan perubahan rencana tindakan pada siklus selanjutnya dengan mengacu pada hasil refleksi sebelumnya.

\section{Tehnik Analisis Data}

Analisis data yang digunakan dalam penelitian ini adalah analisis deskriptif kuantitatif dan kualitatif. Analisis deskriptif kuantitatif digunakan untuk menganalisis skor hasil tes terkait dengan hasil belajar dengan menggunakan model inquiry. Selanjutnya hasil tes tersebut dikomparasikan yaitu membandingkan nilai antar siklus dalam penerapan model inquiry dengan nilai tes sebelum dilakukan tindakan.
Analisis deskriptif kualitatif dalam penelitian ini digunakan untuk menganalisis data hasil observasi. Data yang diperoleh dari hasil observasi terkait dengan keberlangsungan proses pembelajaran dengan menggunakan model inkuiri termasuk hambatanhambatan yang terjadi.

Untuk menganalisis tingkat keberhasilan atau persentase keberhasilan siswa setelah proses belajar mengajar setiap putarannya dilakukan dengan cara memberikan evaluasi berupa soal tes tertulis pada setiap akhir putaran.

Analisis ini dihitung dengan

menggunakan statistik sederhana yaitu:

1. Nilai Ulangan Formatif

Rata-rata nilai tes formatif dapat dirumuskan:

$$
X=\frac{\Sigma \mathrm{n}}{\Sigma \mathrm{s}}
$$

Keterangan:

$X=$ Nilai rata-rata

$\Sigma \mathrm{n}=$ Jumlah semua nilai siswa

$\Sigma s=$ Jumlah seluruh siswa

2. Ketuntasan Belajar

Ada dua kategori ketuntasan belajar yaitu secara perorangan dan secara klasikal. Berdasarkan petunjuk criteria keberhasilan yang telah ditetapkan yaitu seorang siswa telah tuntas belajar bila telah mencapai skor $70 \%$ atau nilai 70 , dan kelas disebut tuntas belajar bila di kelas tersebut $80 \%$ yang telah mencapai daya serap lebih dari atau sama dengan $80 \%$. Untuk menghitung persentase ketuntasan belajar digunakan rumus sebagai berikut:

$$
P=\frac{\Sigma \mathrm{nt}}{\Sigma \mathrm{s}} \quad \times 100 \%
$$

Keterangan:

$P \quad=$ Persentase rata-rata

$\Sigma$ st $=$ Jumlah siswa tuntas

$\Sigma N=$ Jumlah siswa

Kriteria Keberhasilan 
Penelitian tindakan ini dikatakan berhasil jika memenuhi kriteria-kriteria keberhasilan sebagai berikut:

1. Daya serap siswa secara individual mencapai atau lebih dari KKM 70.

2. Ketuntasan belajar secara klasikal jika $\geq$ $80 \%$ siswa telah tuntas.

\section{C.Hasil Penelitian dan Pembahasan Hasil Penelitian \\ SIKLUS I \\ Perencanaan Tindakan Siklus I}

Pelaksanaan tindakan siklus 1 didasarkan pada hasil dari pra tindakan dengan tujuan untuk meningkatkan hasil belajar IPS siswa kelas V SD Negeri 59 Bengkulu Utara. Pada tahap perancanaan ini peneliti menyusun rencana tindakan yang akan dilaksanakan antara lain sebagai berikut: Menentukan waktu pelaksanaan tindakan. Menyusun RPP ( Rencana Pelaksanaan Pembelajaran) Kompetensi Dasar faktor pemicu terjadinya beberapa peristiwa pertempuran dengan menggunakan model inquiry. Menyiapkan LKS (Lembar Kerja Siswa) Menyiapkan dan menyusun instrumen penelitian meliputi: Soal tes. Lembar observasi aktivitas guru dan siswa.

\section{Pelaksanaan Tindakan Siklus I}

Pelaksanaan tindakan siklus I ini dilakukan pada hari Rabu, 12 Maret 2594 berdasarkan perencanaan yang telah dibuat. Peneliti memulai dengan memberikan salam, kemudian mengajak siswa berdoa, mengecek kehadiran, menanyakan kesiapan siswa belajar, guru mengajak siswa menyanyikan lagu "Halo-halo Bandung", kemudian memberikan appersepsi sedikit terkait lagu yang dinyanyikan. Selanjutnya guru menjelaskan kegiatan pembelajaran yang akan dilakukan yang sesuai dengan tahapan-tahapan dalam model inquiry.

Kegiatan inti diawali dengan siswa mendengarkan penjelasan guru terkait dengan KD "perjuangan para pahlawan dalam mempertahankan kemerdekaan". Setelah menjelaskan sedikit terkait dengan perjuangan para pahlawan, guru menjelaskan sekali lagi kepada siswa terkait dengan pokok-pokok kegiatan yang akan dilakukan karena sebelumnya guru belum pernah menerapkan model inkuiri dalam pembelajaran. Selanjutnya, siswa dibagi dalam 4 kelompok dan tiap kelompok terdiri atas 5 dan 6 orang. Pembagian kelompok ini sesuai dengan tempat duduk siswa dengan tujuan untuk memperhemat waktu. Dalam kelompok, siswa mulai menyelesaikan LKS sesuai dengan tahapan-tahapan pada model inquiry.

Setelah membuat pertanyaan, siswa kemudian merumuskan hipotesis dari pertanyaan yang telah dibuat tanpa melihat buku atau sumber referensi atau dengan kata lain bahwa jawabannya berdasarkan apa yang siswa ketahui. Siswa kemudian diarahkan untuk melihat buku yang relevan yaitu buku pegangan siswa dan mencari materi yang terkait dengan topik yang dibahas untuk mendapatkan informasi yang sebenarnya guna menjawab pertanyaan yang telah dibuat sebelumnya. Siswa mencatat informasi-informasi yang didapat dari buku sumber yang dapat menjawab pertanyaan-pertanyaan yang telah dirumuskan sebelumnya pada kolom yang telah disediakan.

Siswa kemudian melakukan uji hipotesis yaitu melihat kesesuaian antara hipotesis yang telah dibuat dari informasi yang didapatkan. Pada uji hipotesis ini, siswa menentukan apakah hipotesis yang telah dibuat dapat dipertahankan karena sesuai dengan informasi yang diperoleh atau tidak digunakan karena tidak sesuai dengan informasi yang telah didapatkan. Setelah melakukan uji hipotesis, siswa kemudian membuat kesimpulan terkait dengan topik yang dibahas berdasarkan pada informasi yang telah diperoleh. Setelah semua kegiatan dilaksanakan, siswa menyampaikan hasil kerjanya. Pada kegiatan ini, siswa memilih salah satu perwakilan dari kelompok untuk membacakan hasil kerja kelompok di depan kelas. Saat sedang melakukan presentasi, siswa yang lain diminta mendengarkan dan mencatat hal-hal penting yang disampaikan kemudian memberikan pertanyaan. Kelompok yang presentasi menjawab pertanyaan yang diajukan dan jika tidak bisa maka akan 
dibantu oleh guru. Pada akhir presentasi, guru memberikan kesimpulan secara umum guna untuk menyamakan persepsi siswa terkait dengan topik yang dibahas.

Pada kegiatan penutup siklus I, guru belum maksimal mengajak siswa menarik kesimpulan dari permasalahan yang telah diperoleh. Pada kegiatan ini, guru memberikan lembar soal kepada siswa terkait topik-topik yang telah dibahas dan siswa menjawab pertanyaan-pertanyaan tersebut. Selanjutnya guru menutup pelajaran IPS dengan memberi salam kepada siswasiswanya.

Pelaksanaan tes pada akhir siklus bertujuan untuk mengetahui sejauh mana pengaruh dari penerapan model Inkuri dalam pembelajaran IPS terkait dengan Kompetensi Dasar perjuangan mempertahankan kemerdekaan siswa kelas V SDN 59 Bengkulu Utara. Tes tersebut terdiri dari 10 soal yang mencakup nama-nama tokoh perjuangan serta usaha para tokoh dalam mempertahankan kemerdekaan. Dari hasil tersebut sebagian siswa masih ada yang menjawab salah. Setelah dikoreksi oleh peneliti ada satu siswa yang mendapatkan nilai terendah 45 dan 1 siswa dengan nilai tertinggi adalah 95 . Adapun hasil tes uraian yang diperoleh siswa kelas V SDN 59 Bengkulu Utara sebagai berikut:

Tabel 1. Data Hasil Belajar Siswa Siklus I

\begin{tabular}{|c|c|c|c|c|c|}
\hline \multirow[b]{2}{*}{ No } & \multirow[b]{2}{*}{ Nama Siswa } & \multicolumn{4}{|c|}{ Siklus } \\
\hline & & $\mathrm{I}$ & Ket & II & Ket \\
\hline 1 & $A$ & 50 & TT & & \\
\hline 2 & AS & 45 & TT & & \\
\hline 3 & $\mathrm{BD}$ & 70 & $\bar{T}$ & & \\
\hline 4 & $\mathrm{BHZ}$ & 75 & $\bar{T}$ & & \\
\hline 5 & BR & 80 & $\mathrm{~T}$ & & \\
\hline 6 & CND & 95 & $\mathrm{~T}$ & & \\
\hline 7 & DF & 60 & TT & & \\
\hline 8 & $F$ & 70 & $\mathrm{~T}$ & & \\
\hline 9 & EB & 75 & $T$ & & \\
\hline 10 & EP & 80 & $T$ & & \\
\hline 11 & FN & 60 & TT & & \\
\hline 12 & $\mathrm{FH}$ & 85 & $\bar{T}$ & & \\
\hline 13 & FS & 85 & $\bar{T}$ & & \\
\hline 14 & GAA & 60 & $\overline{\mathrm{TT}}$ & & \\
\hline 15 & GMP & 70 & $\bar{T}$ & & \\
\hline 16 & GV & 80 & $\bar{T}$ & & \\
\hline 17 & MA & 75 & $T$ & & \\
\hline 18 & MR & 80 & $\mathrm{~T}$ & & \\
\hline 19 & MSI & 75 & $T$ & & \\
\hline 20 & PA & 70 & $T$ & & \\
\hline 21 & $R$ & 60 & TT & & \\
\hline 22 & SNS & 75 & $\mathrm{~T}$ & & \\
\hline 23 & YD & 65 & $T$ & & \\
\hline
\end{tabular}




\begin{tabular}{|c|c|c|c|c|}
\cline { 2 - 5 } Jumlah & 1.640 & & & \\
\hline Rata-rata & 71 & & & \\
\hline Tuntas & $74 \%$ & 17 siswa & & \\
\hline Tidak tuntas & $26 \%$ & 6 siswa & & \\
\hline
\end{tabular}

Keterangan :

\begin{tabular}{|c|c|}
\hline Nilai & Keterangan \\
\hline $70-100$ & Tuntas $(\mathrm{T})$ \\
\hline$<70$ & Tidak Tuntas (TT) \\
\hline
\end{tabular}

Berdasarkan data pada tabel $4.1 \mathrm{di}$ atas dapat dilihat bahwa terjadi peningkatan pada siklus I yang berarti melalui model inquiry, ini hasil belajar IPS siswa kelas V SDN 59 Bengkulu Utara dibandingkan data hasil belajar sebelum tindakan ini terjadi ada perubahan. Pada pelaksanaan siklus I dimana proses pembelajaran sudah menerapkan model Inkuiri hasil tes siswa menunjukan bahwa 17 siswa atau $74 \%$ dari jumlah siswa yang sudah bisa mencapai KKM dan berarti siswa yang belum mencapai KKM sebanyak 6 siswa atau $26 \%$.

Tentu saja hal ini juga berpengaruh pada hasil terhadap nilai ketuntasan klasikal sehingga jumlah siswa yang sudah mencapai KKM belum mencapai target yang diharapkan yaitu $80 \%$ dari jumlah siswa maka siklus I dikatakan

belum berhasil sehingga perlu diadakan siklus II.

\section{Observasi Siklus I}

Observasi atau pengamatan pada siklus I dilakukan oleh observer guna untuk melihat pelaksanaan atau penerapan model Inkuiri di dalam proses pembelajaran baik guru maupun siswa. Pengamatan ini menggunakan lembar observasi kegiatan guru dan siswa dalam menerapkan model Inquiry. Adapun deskripsi penjabaran dari hasil observasi sebagai berikut:

Aktivitas Guru pelaksanaan proses pembelajaran dengan menggunakan model Inquiry untuk penyajian KD "perjuangan para pahlawan dalam mempertahankan kemerdekaan" yang dilakukan guru berdasarkan lembar observasi secara umum dapat dilihat pada tabel berikut ini:

Tabel 2. Hasil Pengamatan Aktifitas Guru Pada Siklus I

\begin{tabular}{|c|c|c|}
\hline \multirow{8}{*}{$\begin{array}{l}\text { Penerapan } \\
\text { model Inquiry } \\
\text { dalam proses } \\
\text { pembelajaran }\end{array}$} & Aktifitas Guru & $\begin{array}{l}\text { Skor } \\
1-4\end{array}$ \\
\hline & $\begin{array}{l}\text { a) Menjelaskan topik tujuan dan hasil belajar yang } \\
\text { akan dicapai }\end{array}$ & 3 \\
\hline & $\begin{array}{l}\text { Menjelaskan pokok-pokok kegiatan yang } \\
\text { harus dilakukan siswa serta tujuannya. }\end{array}$ & 3 \\
\hline & $\begin{array}{l}\text { c) Menjelaskan pentingnya topik dalam kegiatan } \\
\text { belajar }\end{array}$ & 3 \\
\hline & $\begin{array}{l}\text { d) Mendorong siswa untuk berpikir guna } \\
\text { menemukan masalah }\end{array}$ & 3 \\
\hline & $\begin{array}{l}\text { e) Membimbing siswa untuk merumuskan } \\
\text { permasalahan dalam bentuk pertanyaan }\end{array}$ & -- \\
\hline & $\begin{array}{l}\text { f) Memberikan pertanyaan yang mendorong } \\
\text { siswa merumuskan jawaban sementara }\end{array}$ & 2 \\
\hline & $\begin{array}{l}\text { g) Membimbing siswa menjawab pertanyaan guna } \\
\text { menemukan berbagai kemungkinan jawaban } \\
\text { dari permasalahan yang dikaji }\end{array}$ & 3 \\
\hline
\end{tabular}




\begin{tabular}{|c|c|c|c|}
\hline & $\begin{array}{l}\text { h) Mendorong siswa } \\
\text { dan berpikir dengar } \\
\text { pertanyaan yang } \\
\text { berpikir }\end{array}$ & $\begin{array}{l}\text { untuk terus belajar } \\
\text { memberikan pertanyaan- } \\
\text { merangsang siswa untuk }\end{array}$ & 2 \\
\hline & $\begin{array}{l}\text { i) Mengarahkan siswa } \\
\text { informasi yang dibu }\end{array}$ & $\begin{array}{l}\text { untuk mencari informasi- } \\
\text { tuhkan }\end{array}$ & 3 \\
\hline & $\begin{array}{l}\text { j) Membimbing siswa } \\
\text { tepat berdasarkan } \\
\text { diperoleh diperoleh }\end{array}$ & $\begin{array}{l}\text { menentukan jawaban yang } \\
\text { informasi dan data yang }\end{array}$ & -- \\
\hline & $\begin{array}{l}\text { k) Membimbing siswa } \\
\text { permasalahan yang }\end{array}$ & $\begin{array}{l}\text { membuat kesimpulan dari } \\
\text { dibahas }\end{array}$ & -- \\
\hline & Jumlah & & 20 \\
\hline & Kriteria & & Cukup \\
\hline Keterangan & & & \\
\hline Jumlah Nila & & Kriteria & \\
\hline $36-44$ & & Amat Baik ( $A B$ ) & \\
\hline $24-35$ & & Baik ( B ) & \\
\hline $12-23$ & & Cukup ( C ) & \\
\hline $0-11$ & & Kurang ( K ) & \\
\hline
\end{tabular}

Berdasarkan data dari lembar observasi guru tersebut dapat dilihat bahwa pelaksanaan proses pembelajaran dengan menerapkan model Inquiry telah dilakukan dengan cukup baik oleh guru. Namun Tahapan dalam model Inquiry belum diterapkan dengan baik pada siklus I dimana ketika memberi instruksi dari beberapa tahapan model inquiry belum terlalu jelas dan bimbingan guru juga masih kurang terlebih ketika merumuskan hipotesis dan merumuskan kesimpulan. Kemudian dalam mengumpulkan data atau mencari informasi sumber yang digunakan sangat terbatas karena guru hanya menyarankan siswa untuk mencari dari sumber atau pada buku pegangan siswa saja.

Aktifitas siswa dalam proses pembelajaran melalui penerapan model Inkuiri berdasarkan data dari observasi secara umum dapat dilihat pada tabel Aktifitas siswa dalam proses pembelajaran melalui penerapan model Inquiry berdasarkan data dari observasi secara umum dapat dilihat pada tabel 4.3 berikut:

Tabel 3. Hasil Pengamatan Aktifitas Siswa Pada Siklus I

\begin{tabular}{|c|c|c|}
\hline \multirow{10}{*}{$\begin{array}{l}\text { Penerapan } \\
\text { model Inquiry } \\
\text { dalam proses } \\
\text { pembelajaran }\end{array}$} & Aktifitas Siswa & \multirow{2}{*}{$\frac{\text { Ket }}{3}$} \\
\hline & $\begin{array}{l}\text { a) Memperhatikan penjelasan guru tentang topik tujuan } \\
\text { dan hasil belajar yang ingin dicapai }\end{array}$ & \\
\hline & $\begin{array}{l}\text { b) Siswa memperhatikan penjelasan pokok kegiatan } \\
\text { yang akan dilakukan }\end{array}$ & 3 \\
\hline & $\begin{array}{l}\text { c) Memperhatikan penjelasan pentingnya topik dalam } \\
\text { kegiatan belajar }\end{array}$ & 3 \\
\hline & d) Siswa berpikir guna menemukan masalah & 3 \\
\hline & e) Merumuskan permasalahan & -- \\
\hline & $\begin{array}{l}\text { f) Berpikir untuk menemukan jawaban atas } \\
\text { pertanyaannya }\end{array}$ & 2 \\
\hline & $\begin{array}{l}\text { g) Menjawab pertanyaan guna menemukan } \\
\text { berbagai kemungkinan jawaban dari permasalahan } \\
\text { yang dikaji }\end{array}$ & 2 \\
\hline & $\begin{array}{l}\text { h) Belajar dan berpikir untuk } \\
\text { pertanyaan- }\end{array}$ & 3 \\
\hline & i) Mencari informasi yang dibutuhkan & -- \\
\hline
\end{tabular}




\begin{tabular}{|c|l|c|}
\hline & $\begin{array}{l}\text { j) Menentukan jawaban yang tepat berdasarkan } \\
\text { informasi dan data yang diperoleh }\end{array}$ & -- \\
\hline k) Membuat kesimpulan dari permasalahan yang dibahas & -- \\
\hline Jumlah & 19 \\
\hline Kriteria & Cukup \\
\hline
\end{tabular}

Keterangan :

\begin{tabular}{|l|l|}
\hline \multicolumn{1}{|c|}{ Jumlah Nilai } & \multicolumn{1}{c|}{ Kriteria } \\
\hline $36-44 \quad$ & Amat Baik (AB) \\
\hline $24-35$ & Baik (B) \\
\hline $12-23$ & Cukup (C) \\
\hline $0-11$ & Kurang (K) \\
\hline
\end{tabular}

Berdasarkan data observasi kegiatan pembelajaran yang dilakukan oleh siswa melalui model inquiry telah dilakukan dengan cukup baik oleh siswa. Dimana siswa telah ikut serta berpartisipasi dalam kegiatan pembelajaran hanya saja siswa sering bertanya, hal ini disebabkan karena siswa kurang paham langkah-langkah yang harus dilakukan pada tiap-tiap tahapan inkuiri khususnya pada saat merumuskan hipotesis dan merumuskan kesimpulan siswa masih mengalami kesulitan. Hal ini juga dikarenakan kurangnya bimbingan guru ketika melakukan berbagai tahapan dalam model inquiry sehingga hasilnya juga kurang maksimal. Hai lain yang dapat ditemui yang menjadi kekurangan pada siklus I berdasarkan hasil observasi aktivitas siswa adalah sumber yang digunakan siswa untuk mengumpulkan data atau mencari informasi masih terbatas karena siswa hanya berpatokan pada sumber atau buku pegangan siswa sehingg data yang diperoleh siswa juga masih terbatas.

\section{Refleksi Siklus I}

Refleksi pada siklus I dilakukan untuk membahas hal-hal yang menjadi hambatan pada siklus I. Dalam hal ini peneliti dan observer berdiskusi membahas proses tindakan pelaksanaan pembelajaran pada siklus I sehingga dapat diketahui kendala-kendala atau hal-hal yang perlu ditingkatkan serta sebagai acuan untuk melakukan tindakan untuk siklus II. Data hasil pengamatan permasalahan pada siklus I sebagai berikut:

Tabel 4. Permasalahan Pada Siklus I dan Pemecahannya Pada Siklus II

\begin{tabular}{|c|c|c|}
\hline No & Hasil Refleksi Siklus I & Perencanaan pada siklus II \\
\hline 1 & $\begin{array}{l}\text { Siswa masih kesulitan } \\
\text { dalam memahami tahap } \\
\text { merumuskan hipotesis } \\
\text { dan kesimpulan pada } \\
\text { tahapan inkuiri }\end{array}$ & $\begin{array}{l}\text { Guru pada siklus II akan lebih jelas dalam } \\
\text { memberikan instruksi terkait tahapan Inquiry } \\
\text { khususnya pada tahap merumuskan } \\
\text { hipotesis dan merumuskan kesimpulan serta } \\
\text { guru juga memberikan contohnya, selain itu } \\
\text { membimbing siswa pada saat pelaksanaan } \\
\text { tiap-tiap tahapan inkuiri }\end{array}$ \\
\hline
\end{tabular}




\begin{tabular}{|c|c|c|}
\hline 2 & $\begin{array}{l}\text { Pada sa } \\
\text { mengumpulkan dat } \\
\text { atau mencari informa } \\
\text { siswa hanya berpatoka } \\
\text { pada buku peganga }\end{array}$ & $\begin{array}{l}\text { Guru akan mengarahkan siswa untuk } \\
\text { mencari atau mengumpulkan data dari sumber } \\
\text { yang relevan lainnya seperti membawa siswa } \\
\text { ke perpustakaan. }\end{array}$ \\
\hline
\end{tabular}

Berdasarkan tabel 4.4 maka kriteria keberhasilan belum terpenuhi bahwa kompotensi akademik dikatakan berhasil apabila minimal $80 \%$ siswa belum memperoleh nilai 70 , sedangkan capaian tuntas klasikal siklus I baru $74 \%$ sehingga penelitian ini harus dilanjutkan pada siklus II untuk memperbaiki kekurangan pada siklus I.

\section{SIKLUS II \\ Perencanaan Siklus Perbaikan II}

Perencanaan siklus II didasarkan pada hasil refleksi siklus I. Pelaksanaan siklus II sama dengan siklus I baik dari segi Kompetensi Dasar maupun kegaiatan pembelajarannya. Terkait dengan langkah-langkah inquiry pada siklus II difokuskan pada: 1) Pemahaman terkait dengan merumuskan hipotesis dan kesimpulan dengan cara guru memberikan instruksi yang lebih jelas terkait dengan cara merumuskan hipotesis dan kesimpulan. 2) Guru memberikan contoh cara merumuskan hipotesis dan kesimpulan agar siswa lebih paham.

Selain itu, siswa diarahkan untuk mencari informasi di luar kelas yaitu di perpustakaan, hal ini juga bertujuan agar siswa tidak bosan karena proses pembelajaran hanya berlangsung di kelas. Rencana peneliti dalam siklus II yaitu: Menyusun RPP. Menyusun Lembar Observasi. Menyusun soal tes uraian untuk siklus II. Menyusun perencanaan teknik atau cara siswa dalam merumuskan hipotesis dan kesimpulan. Mempersiapkan perpustakaan sekolah.

\section{Pelaksanaan Tindakan Siklus II}

Pelaksanaan tindakan siklus II ini dilakukan pada hari Rabu, 19 Maret 2594 yang merupakan kelanjutan dari tindakan siklus I dengan mengulang kembali Kompetensi Dasar yang sama. Pembelajaran pada siklus II ini diawali dengan guru: 1) Mengucapkan salam. 2) Meminta salah seorang siswa memimpin doa. 3) Mengecek kehadiran. 4) Menanyakan kesiapan siswa untuk belajar. 5) Mengajak siswa menyanyikan lagu "Halo-halo Bandung". 6) Memberikan apersepsi dengan menunjukkan gambar-gambar pahlawan kemudian bertanya jawab terkait dengan gambar-gambar tersebut. 7) Menyampaikan pokok bahasan yang akan dipelajari yaitu perjuangan mempertahankan kemerdekaan. 8) Memberitahukan kegiatan pembelajaran yang akan dilakukan. 9) Menyampaikan cara-cara merumuskan hipotesis dan merumuskan kesimpulan. 10) Membagikan LKS. 11) Memantau siswa dalam kelompok menyelesaikan LKS berdasarkan tahapan-tahapan inquiry dengan tugas merumuskan permasalahan yaitu dengan membuat sebuah pertanyaan dari topik yang telah ditentukan oleh guru yaitu terkait dengan pertempuran di Surabaya, Bandung lautan api, pertempuran medan area, agresi militer Belanda I dan agresi militer Belanda II. 12) Meminta siswa mengumpulkan data atau mencari informasi, sumber dari perpustakaan. 13) Meminta tiap kelompok membahas satu topik saja. 14) Perwakilan kelompok untuk membacakan hasil kerja kelompok di depan kelas. 15) Kelompok lain menanggapi. 16) Jika kelompok yang di depan kelas tidak bisa menjawab maka guru membantu. 17) Guru menyimpulkan secara umum agar ada kesamaan persepsi terkait topik yang dibahas. 18) Soal tes uraian dibagikan. 19) Siswa menyelesaikan soal tes perorangan bertujuan untuk mengetahui sejauh mana proses pembelajaran dan hasil belajar IPS tercapai. 20) Siswa dibantu menyimpulkan materi pembelajaran. dan 
21) Guru menutup pelajaran dengan memberikan penguatan dan memberikan salam.

Setelah dikoreksi sebagian besar siswa sudah bisa menjawab semua soal dengan baik sehingga banyak siswa yang mendapatkan nilai diatas KKM dengan nilai terendah 65 dan nilai tertinggi adalah 95. Adapun hasil dari tes siklus II ini tertera dalam tabel 4.5 berikut:

Tabel 5. Data Hasil Belajar Siswa Siklus II

\begin{tabular}{|c|c|c|c|c|c|}
\hline \multirow[b]{2}{*}{ No } & \multirow[b]{2}{*}{ Nama Siswa } & \multicolumn{4}{|c|}{ Siklus } \\
\hline & & $\mathrm{I}$ & Ket & II & Ket \\
\hline 1 & $A$ & 50 & TT & 70 & $\mathrm{~T}$ \\
\hline 2 & AS & 45 & TT & 65 & TT \\
\hline 3 & $B D$ & 70 & $\mathrm{~T}$ & 80 & $\mathrm{~T}$ \\
\hline 4 & $\mathrm{BHZ}$ & 75 & $\mathrm{~T}$ & 85 & $\mathrm{~T}$ \\
\hline 5 & BR & 80 & $\mathrm{~T}$ & 85 & $T$ \\
\hline 6 & CND & 95 & $\mathrm{~T}$ & 95 & $\mathrm{~T}$ \\
\hline 7 & DF & 60 & TT & 80 & $\mathrm{~T}$ \\
\hline 8 & $E$ & 70 & $\mathrm{~T}$ & 80 & $\mathrm{~T}$ \\
\hline 9 & EB & 75 & $T$ & 75 & $T$ \\
\hline 10 & EP & 80 & $\mathrm{~T}$ & 80 & $\mathrm{~T}$ \\
\hline 11 & FN & 60 & TT & 75 & $\mathrm{~T}$ \\
\hline 12 & $\mathrm{FH}$ & 85 & $T$ & 90 & $T$ \\
\hline 13 & FS & 85 & $\mathrm{~T}$ & 85 & $\mathrm{~T}$ \\
\hline 14 & GAA & 60 & TT & 70 & $\mathrm{~T}$ \\
\hline 15 & GMP & 70 & $\mathrm{~T}$ & 80 & $T$ \\
\hline 16 & GV & 80 & $\mathrm{~T}$ & 90 & $\mathrm{~T}$ \\
\hline 17 & MA & 75 & $\bar{T}$ & 80 & $\bar{T}$ \\
\hline 18 & MR & 80 & $\mathrm{~T}$ & 90 & $\mathrm{~T}$ \\
\hline 19 & $\mathrm{MSI}$ & 75 & $\mathrm{~T}$ & 80 & $T$ \\
\hline 20 & PA & 70 & $T$ & 85 & $T$ \\
\hline 21 & $\mathrm{R}$ & 60 & TT & 75 & $\mathrm{~T}$ \\
\hline 22 & SNS & 75 & $T$ & 85 & $T$ \\
\hline 23 & YD & 65 & $\bar{T}$ & 65 & TT \\
\hline \multicolumn{2}{|c|}{ Jumlah } & 1.640 & & 1.845 & \\
\hline \multicolumn{2}{|c|}{ Rata-rata } & 71 & & 80 & \\
\hline \multicolumn{2}{|c|}{ Tuntas } & $74 \%$ & 17 siswa & $91 \%$ & 21 siswa \\
\hline \multicolumn{2}{|c|}{ Tidak tuntas } & $26 \%$ & 6 siswa & $9 \%$ & 2 siswa \\
\hline
\end{tabular}

Keterangan :
\begin{tabular}{|c|c|}
\hline Nilai & Keterangan \\
\hline $70-100$ & Tuntas $(\mathrm{T})$ \\
\hline
\end{tabular}


\begin{tabular}{|l|l|}
\hline$<70$ & Tidak Tuntas (TT) \\
\hline
\end{tabular}

Adapun ketuntasan belajar siswa berdasarkan perbandingan jumlah siswa yang sudah mencapai KKM saat Siklus
I dan Siklus II dapat dilihat pada bagan berikut:

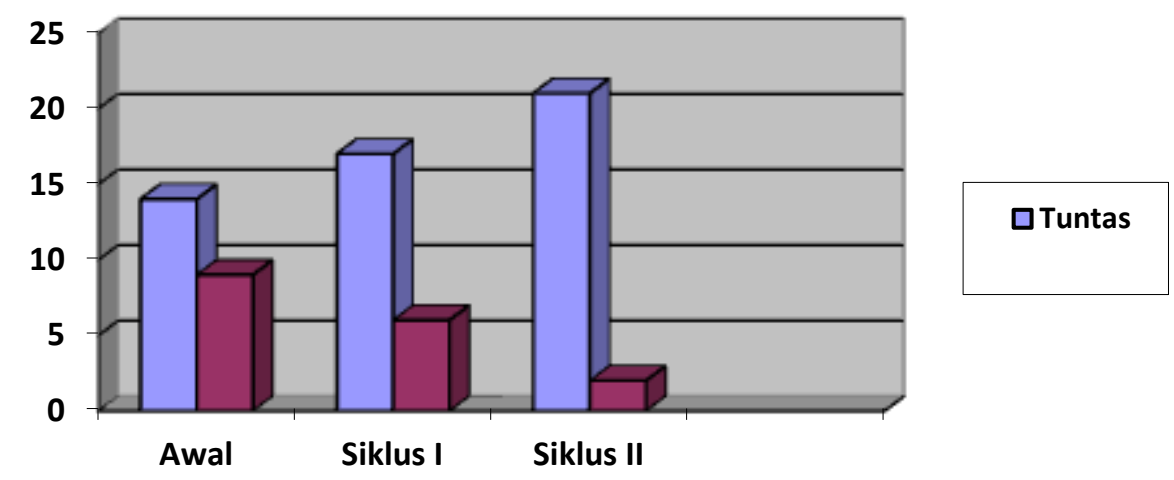

Gambar I. Perbandingan Hasil Belajar Siswa

Berdasarkan data hasil belajar di atas jumlah nilai yang diperoleh siswa pada siklus II adalah 1.845 meningkat 205 jika dibanding jumlah nilai hasil belajar siklus I. Ketuntasan klasikal juga meningkat signifikan dari 17 siswa atau 74\% pada siklus I menjadi 21 siswa atau $91 \%$. Siswa yang nilai hasil belajarnya di bawah KKM juga mengalami penurunan $17 \%$.

Dari hasil belajar siklus II di atas jika di lihat dari criteria ketuntasan klasikal $80 \%$ siswa tuntas dari total siswa maka pelaksanaan tindakan pembelajaran pada siklus perbaikan II ini dapat disebut berhasil sehingga peneliti menyimpulkan bahwa tindakan pembelajaran tidak perlu dilanjutkan kembali.

\section{Observasi Siklus II}

Observasi dilakukan oleh observer bertujuan untuk melihat penerapan dan pelaksanaan dari model Inquiry dalam proses pembelajaran baik aktifitas guru maupun oleh siswa. Pengamatan ini menggunakan instrument observasi aktifitas guru dan siswa dengan hasil sebagai berikut:

\section{Aktifitas Guru}

Pelaksanaan proses pembelajaran dengan menggunakan model Inquiry untuk penyajian indikator perjuangan mempertahankan kemerdekaan yang dilakukan guru berdasarkan lembar observasi secara umum dapat dilihat pada tabel 4.6 berikut:

Tabel 6. Hasil Pengamatan Aktifitas Guru Pada Siklus II

\begin{tabular}{|c|c|c|}
\hline \multirow{8}{*}{$\begin{array}{c}\text { Penerapan } \\
\text { model Inquiry } \\
\text { dalam proses } \\
\text { pembelajaran }\end{array}$} & & \multirow{3}{*}{$\begin{array}{r}\text { Ket } \\
3 \\
3\end{array}$} \\
\hline & \multirow{7}{*}{$\begin{array}{l}\text { Aktifitas Guru } \\
\text { a) Menjelaskan topik tujuan dan hasil belajar yang } \\
\text { akan dicapai } \\
\text { b) Menjelaskan pokok-pokok kegiatan yang harus } \\
\text { dilakukan siswa serta tujuannya. } \\
\text { c) Menjelaskan pentingnya topik dalam kegiatan } \\
\text { belajar } \\
\text { d) Mendorong siswa untuk berpikir guna } \\
\text { menemukan masalah } \\
\text { e) Membimbing siswa untuk merumuskan } \\
\text { permasalahan dalam bentuk pertanyaan } \\
\text { f) Memberikan pertanyaan yang mendorong siswa } \\
\text { merumuskan jawaban sementara } \\
\text { g) Membimbing siswa menjawab pertanyaan guna } \\
\text { menemukan berbagai kemungkinan jawaban dari }\end{array}$} & \\
\hline & & \\
\hline & & 4 \\
\hline & & 3 \\
\hline & & 3 \\
\hline & & 3 \\
\hline & & 3 \\
\hline
\end{tabular}




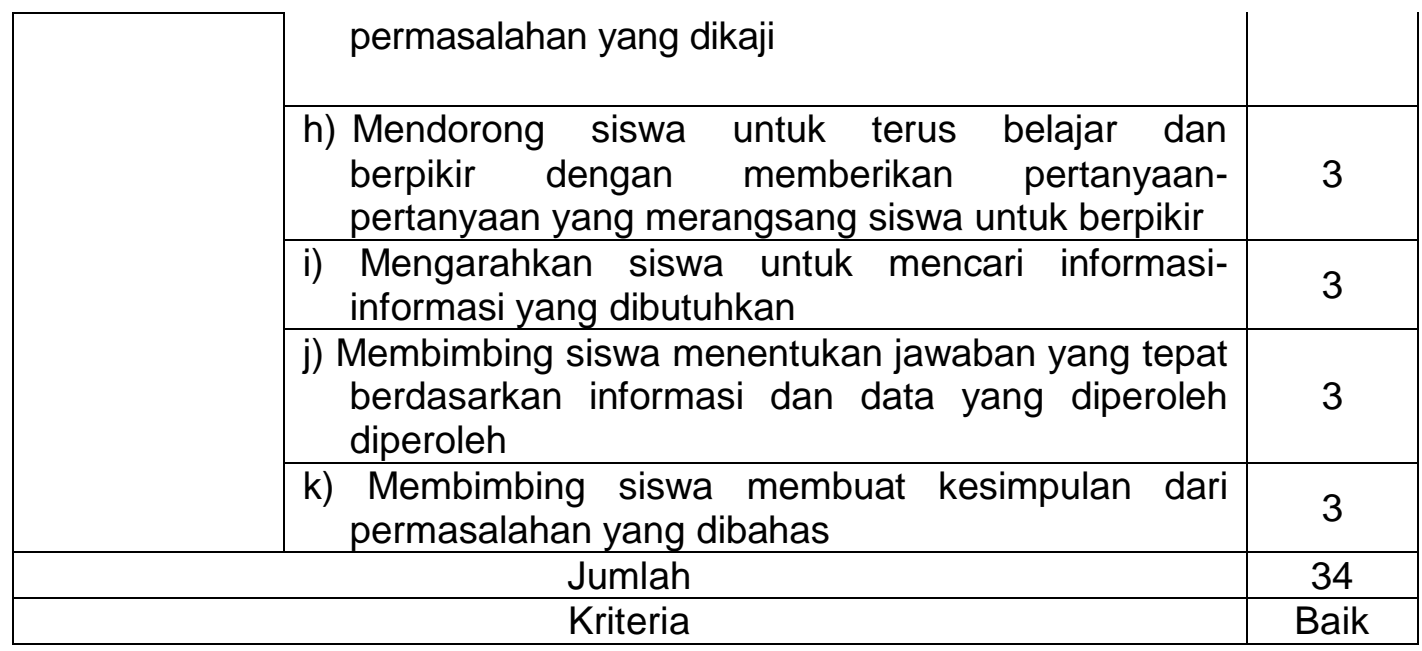

Keterangan :

\begin{tabular}{|l|l|}
\hline Jumlah Nilai & Kriteria \\
\hline $36-44$ & Amat Baik (AB) \\
\hline $24-35$ & Baik (B) \\
\hline $12-23$ & Cukup ( C ) \\
\hline $0-11$ & Kurang (K) \\
\hline
\end{tabular}

Berdasarkan data dari lembar diharapkan. Tidak ada kendala yang observasi guru tersebut dapat dilihat bahwa pelaksanaan proses tindakan pembelajaran dengan menerapkan model Inquiry sudah dilakukan dengan baik oleh guru. Tahapan dalam model Inquiry sudah guru terapkan dengan baik pada siklus II sesuai dengan yang ditemui oleh guru dalam menerapkan proses pembelajaran melalui model Inquiry.

Aktifitas siswa dalam proses pembelajaran siklus II melalui penerapan model Inquiry berdasarkan data pengamatan dari observer secara umum dapat dilihat pada tabel 4.7 berikut:

Tabel 7. Hasil Pengamatan Aktifitas Siswa Pada Siklus II

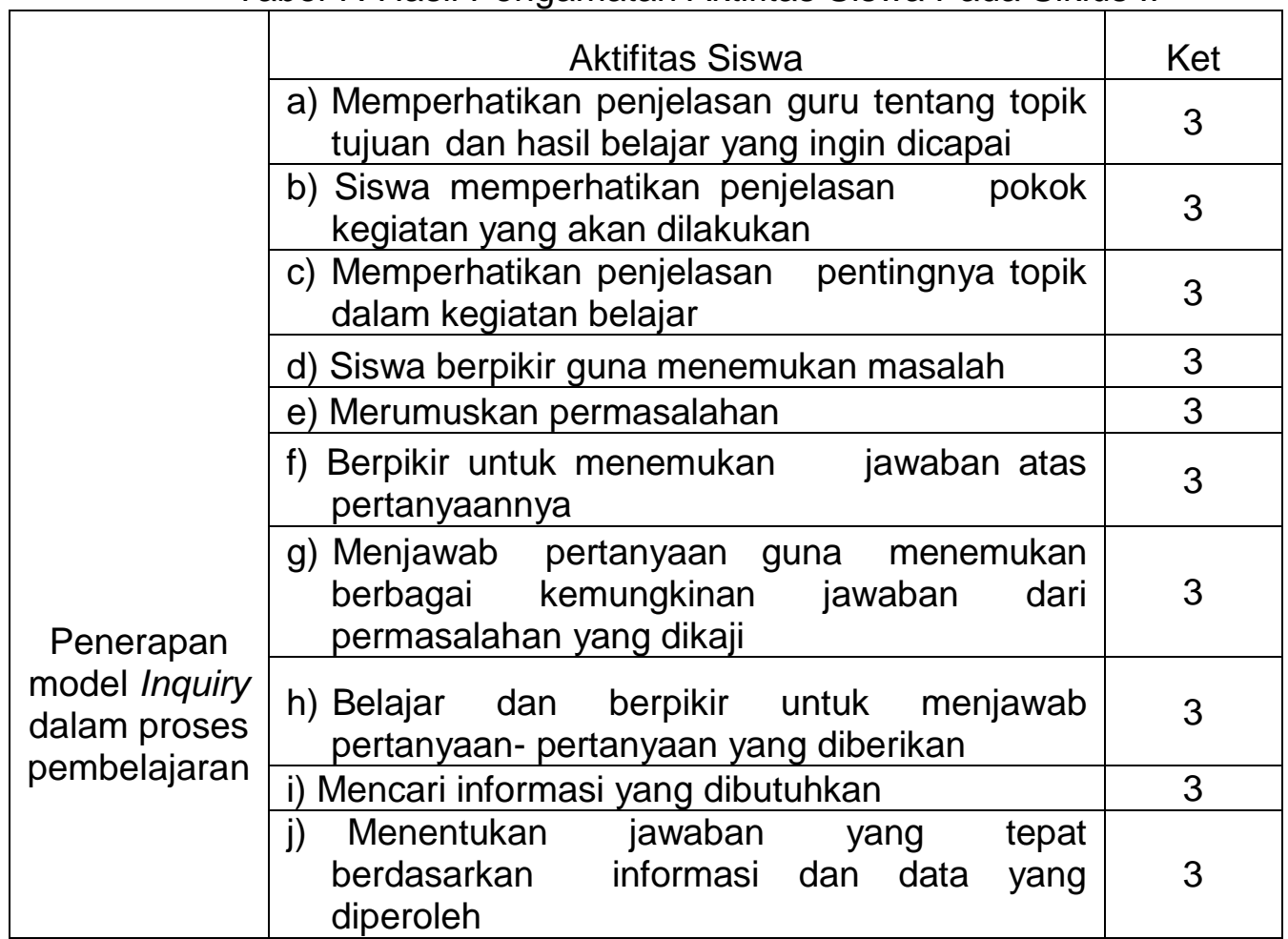




\begin{tabular}{|c|c|}
\hline $\begin{array}{c}\text { k) Membuat kesimpulan dari permasalaahan } \\
\text { yang dibahas }\end{array}$ & 3 \\
\hline Jumlah & 33 \\
\hline Kriteria & Baik \\
\hline
\end{tabular}

Keterangan :

\begin{tabular}{|l|l|}
\hline \multicolumn{1}{|c|}{ Jumlah Nilai } & \multicolumn{1}{c|}{ Kriteria } \\
\hline $36-44 \quad$ & Amat Baik (AB) \\
\hline $24-35$ & Baik (B) \\
\hline $12-23$ & Cukup (C) \\
\hline $0-11$ & Kurang ( K) \\
\hline
\end{tabular}

Berdasarkan data observasi kegiatan pembelajaran yang dilakukan oleh siswa melalui model Inquiry secara umum semuanya telah berjalan dengan baik. Dimana siswa telah ikut serta berpartisipasi aktif dan mengikuti arahan guru untuk melaksanakan setiap tahapan atau kegiatan pembelajaran sesuai dengan tahapan Inquiry.

\section{Refleksi Siklus II}

Pelaksanaan

tindakan pembelajaran siklus II melalui penerapan model Inquiry telah berjalan dengan baik sesuai dengan yang ingin dicapai oleh peneliti. Dimana kekurangan yang terdapat pada siklus I sudah diatasi dengan cara guru sudah menjelaskan tahap-tahap Inquiry dengan lebih jelas sehingga siswa memahami tiap tahaptahap tersebut dan tidak lagi bertanya ataupun kebingungan dalam mengerjakan tugas LKS sesuai tahap Inquiry terutama pada tahapan merumuskan hipotesis dan merumuskan kesimpulan. kemudian dalam mengumpulkan data atau informasi sudah diarahkan untuk mencari informasi pada sumber yang relevan dengan mengarahkan siswa untuk mencari dari buku-buku di perpustakaan, hal ini dilakukan sebagai upaya untuk dapat memperbaiki kekurangan yang terjadi pada siklus I dan semuanya telah berjalan dengan baik.

Teratasinya kendala pada siklus I membuat proses pembelajaran pada siklus II berjalan dengan optimal sehingga proses pembelajaran dan hasil belajar siswa dapat meningkat dengan jumlah siswa yang sudah mencapai $K K M \geq 70$ sebanyak 21 siswa dengan persentase 91\%. Berdasarkan hasil refleksi untuk siklus II maka tindakan yang dilakukan oleh peneliti adalah $u$ penelitian dihentikan karena sudah mencapai criteria keberhasilan yang telah ditetapkan yakni $80 \%$.

\section{Pembahasan}

Kegiatan tindakan pembelajaran dengan menerapkan model Inquiry dalam pembelajaran IPS pada penelitian ini membahas Kompetensi Dasar terkait dengan Perjuangan mempertahankan kemerdekaan. Adapun tahapan kegiatan dalam model Inquiry ini dimulai dengan orientasi dimana siswa akan memperhatikan penjelasan guru terkait topik pembelajaran yang akan dibahas dan penjelasan dari tahapan-tahapan Inquiry, merumuskan masalah, merumuskan hipotesis, mengumpulkan data atau mencari informasi, menguji hipotesis dan yang terakhir merumuskan kesimpulan. Serangkaian kegiatan tersebut akan membuat siswa menjadi lebih aktif.

Penerapan model Inquiry pada pembelajaran IPS, membuat proses tindakan pembelajaran yang awalnya membosankan dan hanya berpusat pada guru menjadi lebih menyenangkan dan membuat siswa lebih aktif dalam proses pembelajaran. Partisipasi aktif siswa selama proses pembelajaran dengan menerapkan model Inquiry baik untuk siklus I maupun siklus II meningkat.

Pada siklus I guru menerapkan model Inquiry pada mata pelajaran IPS dengan Kompetensi Dasar "Perjuangan mempertahankan kemerdekaan serta tokoh-tokoh nasional". Pada pelaksanaan tindakan pembelajaran 
guru sudah melaksanakan sesuai dengan rencana pelaksanaan pembelajaran. Guru sudah menerapkan model Inquiry secara optimal agar pembelajaran berjalan dengan baik dan lancar. Siswa dibimbing agar mampu mencari informasi dari sumber-sumber yang relevan terkait dengan materi ataupun topik yang diberikan sehingga menjadikan siswa.

Berangkat dari observasi awal sebelum tindakan siklus I, ketuntasan belajar siswa masih terbilang kurang memuaskan. Sebanyak 14 siswa dinyatakan tuntas hasil belajarnya dengan presesntase sebesar $61 \%$. Sedangkan siswa dengan nilai kurang dari KKM sebanyak 9 siswa dengan presentase sebesar 39\%. Hal ini disebabkan oleh cara guru dalam mengajar masih menggunakan metode ceramah yang mengakibatkan siswa pasif dan kurang aktif, siswa juga nampak ada kebosanan selama pembelajaran berlangsung sampai dengan saat evaluasi atau tes sehingga mengakibatkan hasil belajar siswa rendah.

Setelah adanya tindakan pada siklus I, jumlah siswa dengan nilai tuntas mencapai 17 siswa dengan presentase sebanyak $74 \%$, sedangkan siswa dengan nilai belum tuntas sebanyak 6 siswa dengan presentase sebesar $26 \%$. Senada dengan siklus I, pada siklus II hasil belajar siswa juga mengalami peningkatan. Jumlah siswa yang mencapai KKM sebanyak 21 orang atau tuntas $91 \%$ terjadi peningkatan ketuntasan $17 \%$ dan hanya dua siswa yang belum dapat memenuhi KKM.

Selain itu, aktivitas guru dalam kegiatan pembelajaran melalui penerapan metode demonstrasi juga mengalami kenaikan skor. Aktivitas guru pada siklus I mencapai skor total 20 berdasarkan kriteria penilaian masuk kategori cukup. Pada siklus II sudah berjalan seperti yang diharapkan sehingga aktivitas guru termasuk kategori baik, aktivitas guru meningkat mencapai total skor 34. Sedang aktivitas siswa dalam pembelajaran IPS Kompetensi Dasar "Perjuangan mempertahankan kemerdekaan serta tokoh-tokoh nasional" pada siklus I mencapai skor 19 kategori cukup dan di siklus II mencapai skor 33 kategori baik. Dari pembahasan di atas dapat disimpulkan bahwa penerapan model Inquiry pada Kompetensi Dasar "Perjuangan mempertahankan kemerdekaan serta tokoh-tokoh nasional" di kelas $\mathrm{V}$ tahun pelajaran 2593/2594 dapat dikatakan bahwa model pembelajaran Inquiry lebih fleksibel untuk diimplementasikan karena mampu meningkatkan hasil belajar siswa.

\section{Kesimpulan dan Hasil Kesimpulan}

Berdasarkan hasil pelaksanaan tindakan pembelajaran yang dilaksanakan sebanyak dua siklus, dapat diambil kesimpulan bahwa:Penerapan model pembelajaran Inquiry dapat meningkatkan hasil belajar IPS siswa kelas V SD Negeri 59 Bengkulu Utara tahun pelajaran 2593/2594. Pada kegiatan evaluasi proses tindakan menunjukkan bahwa ketuntasan klasikal siklus I adalah $74 \%$ dan meningkat di siklus II menjadi $91 \%$. Siswa yang tuntas di siklus I adalah 17 siswa atau $74 \%$ dan pada siklus perbaikan menjadi 21 siswa atau $91 \%$.

\section{Saran}

Berdasarkan hasil penelitian yang telah dipaparkan sebelumnya maka peneliti memberikan saran sebagai berikut: Pembagian kelompok atau pasangan harus dilakukan oleh guru dengan menggabungkan yang pintar dengan yang kurang pintar agar bisa saling membantu. Pembagian tugas kelompok sebaiknya tiap masing-masing anggota kelompok diberi tugas atau tanggung jawab agar siswa lebih fokus dan serius dalam pembelajaran dan belajar untuk bertanggung jawab terhadap tugas yang diberikan. Sebaiknya guru menerapkan model pembelajaran yang bervariasi yaitu model Inquiry sehingga siswa terlibat aktif dalam kegiatan pembelajaran. 


\section{Daftar Pustaka}

Ahmad Susanto. (2594). Pengembangan Pembelajaran IPS di Sekolah Dasar. Jakarta : Prenada media Group.

Dadang Supardan. (2595). Pembelajaran IImu Pengetahuan Sosial. Jakarta: PT Bumi Aksara.

Depdiknas (2006). Kurikulum Tingkat Satuan Pendidikan Sekolah Dasar. Jakarta : Depdiknas

Muhammad Fathurrohman. (2595). Model-Model pembelajaran Inovatif. Jogyakarta: Ar-Ruzz Media.

Nana Sudjana. (1990). Penilaian Hasil Proses Belajar Mengajar. Bandung: PT Remaja Rosdakarya.

Purwanto. (2594). Evaluasi Hasil Belajar. Yogyakarta: Pustaka.

Suharsimi Arikunto. (2006). Prosedur Penelitian Suatu Pendekatan Praktik. Jakarta : Rineka Cipta.

Slameto. (2590). Belajar dan Faktorfaktor yang mempengaruhinya. Jakarta: Asdi Mahasatya.

Trianto. (2009). Model Pembelajaran Terpadu dalam Teori dan Praktek. Jakarta: Prestasi Pustaka.

Trianto. (2007). Mendesain Model Pembelajaran Inovatif- Progresif. Jakarta: Kencana Frenadamedia.

Wina Sanjaya. (2006). Strategi Pembelajaran. Bandung: Kencana Frenadamedia. 